\title{
Konferencen og dens resultat
}

Af Henning Bro

Nordøstsjælland har gennem historien udviklet sig til en af landets mest integrerede regioner: Fra middelalderens sundbyer, over enevældens total dominerende hovedstad og til dannelsen af hovedstadsmetropolen op gennem det 20. århundrede og dennes begyndende sammensmeltning med byer og landskaber øst for Øresund efter årtusindeskiftet. Der foreligger en ganske betydelig historisk litteratur om Nordøstsjællands og Skånes enkelte købstæder, landdistrikter og senere stationsbyer og forstæder, men kun få bidrag har belyst hovedstadsområdets udvikling som en interagerende region og dets samspil med Skåne.

\section{Metropolhistorisk konference}

For at sætte fokus på dette uopdyrkede forskningsområde og i et bredere perspektiv tillige på byregional historie i Skandinavien tog organisationen Hovedstadsområdets Kulturhistoriske Arkiver (HOKA), Frederiksberg Stadsarkiv og Dansk Center for Byhistorie, Aarhus Universitet, initiativ til, at der d. 22. august 2019 afholdtes en metropolhistorisk konference på Frederiksberg Rådhus. Knap 50 forskere fra danske og skåneske universiteter, arkiver og museer deltog i konferencen, der efter en kort introduktion bød på følgende seks metropolhistoriske oplæg:

Fra fastningsby til Øresundsmetropol - de lange linjer, v. Henning Bro, stadsarkivar, Ph.d., Frederiksberg Stadsarkiv

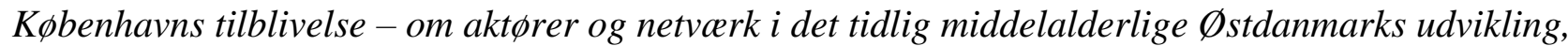
v. Hanna Sofia Strandmark Dahlström, museumsinspektør, Ph.d., Københavns Museum

København og Malmø indtil 1660, v. Ebbe Nyborg, cand.mag., Nationalmuseet.

Københavns opland i førindustriel tid, v. Jørgen Mikkelsen, seniorforsker, Ph.d., Rigsarkivet.

"Byens Husmoend" og andre overlejrede bybyggere -om tilblivelsen af københavnske forstadslandskaber, v. Poul Sverrild, museumschef MSO, Ph.d., Forstadsmuseet

Malmø-regionen i årtierne omkring årtusindeskiftet, v. Kent Andersson, tidligere borgmester (S), Malmö Stad

\section{Metropolhistorisk Netværk}

Ved konferencens afslutning besluttede 42 af deltagerne at oprette Metropolhistorisk Netværk. Netværket fik til formål at fremme forskningen i det danske hovedstadsområdes regionale historie, herunder Øresundsregionens historie, at bidrage til den nationale og internationale byregionale historieforskning for tiden efter $1850 \mathrm{og}$ i den forbindelse at søge samarbejde med danske og internationale forskningsmiljøer inden for dette område.

Henning Bro, Ph.d., stadsarkivar em MSO, byhistorisk konsulent, Frederiksberg Stadsarkiv. 
Ved oprettelsen af Metropolhistorisk Netværk blev Frederiksberg Stadsarkiv netværkets værtinstitution med en styregruppe omfattede:

Caspar Christiansen, mag. art., it-arkivar, senere stadsarkivar, ved Frederiksberg Stadsarkiv og formand for HOKA.

Lisbeth Hollensen, cand.mag., museumsinspektør ved Forstadsmuseet og medlem af bestyrelsen for HOKA

Lene Skodborg, mag. art. og museumsinspektør ved Østsjællands Museum samt projektleder og rådgiver ved Kulturmiljøer Langs Letbanen

Mikkel Thelle, Ph.d., lektor ved Aarhus Universitet og leder af Dansk center for Byhistorie

Henning Bro, Ph.d. og stadsarkivar, senere stadsarkivar em MSO, Byhistorisk Konsulent, ved Frederiksberg Stadsarkiv

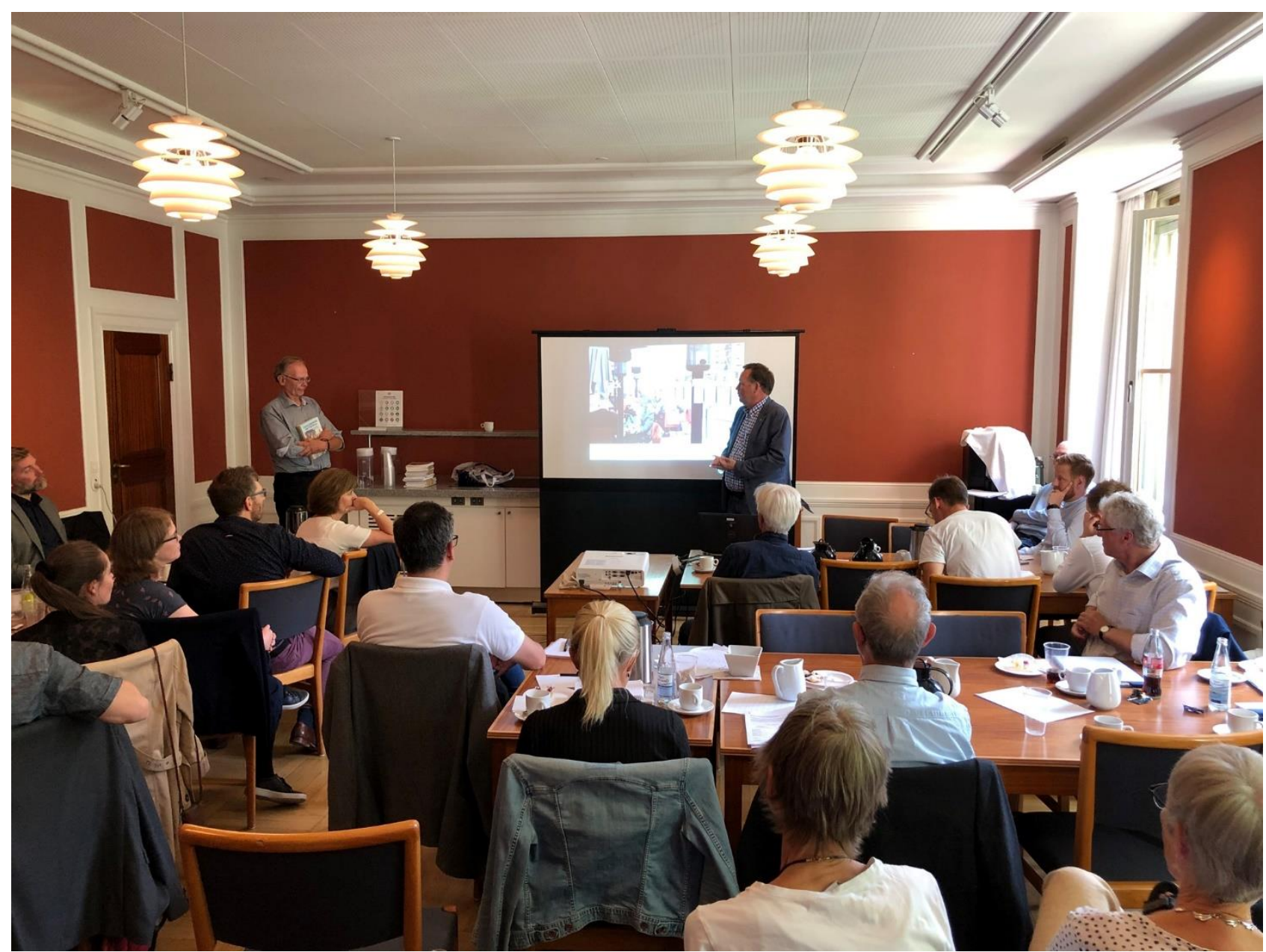

Fra Metropolhistorisk Konference 2019 på Frederiksberg Rådshus. I baggrunden ses: Til højre: Kent Andersson, tidligere borgmester (S), Malmö Stad, og til venstre: tidligere stadsarkivar Henning Bro, Frederiksberg Stadsarkiv (Foto: Lars Schreiber Pedersen, Frederiksberg Stadsarkiv). 
I et samarbejde mellem værtinstitutionen og styregruppen har Metropolhistorisk Netværk siden konferencen udsendt tre nyhedsbreve, oprettet hjemme- og Facebooksider, lagt de redaktionelle rammer for netværket digitale tidskrift METROPOL og påbegyndt arbejdet med tilrettelæggelse af en metropolhistorisk konference senere i 2020. Kredsen af netværksdeltagere er siden konferencen udvidet, således at den p.t. omfatter 53 personer.

Alle der kan tilslutte sig Metropolhistorisk Netværks formål, er særdeles velkomne til at indgå i netværkskredsen. En deltagelse, der er helt uforpligtende, idet det er op til den enkelte både at deltage i Metropolhistorisk Netværks kommende arrangementer, seminaner og forskningsprojekter, der fremgår af netværkets hjemmeside, eller at bidrage til tidskiftet METROPOL.

\section{Summary}

In August 2019, the first metropolitan historical conference was held in Denmark. Behind the conference was the organization The Capital Area Cultural History Archives (Hovedstadsområdets Kulturhistoriske Arkiver (HOKA)), Frederiksberg City Archives (Frederiksberg Stadsarkiv) and the Danish Center for Urban History, University of Aarhus (Dansk Center for Byhistorie, Aarhus Universitet).

At the end of the conference, the participants decided to create the Metropolitan Historical Network. The network aimed to promote research in the regional history of the Danish metropolitan area, including the regional history of the Øresund-region, to contribute to the national and international urban regional history research for the post-1850 period and to seek collaboration with Danish and international research communities in this area.

When establishing the Metropolitan Historical Network, the Frederiksberg City Archives hosted the network with a steering committee of:

Caspar Christiansen, MA, Frederiksberg City Archives and chairman of HOKA.

Lisbeth Hollensen, MA, The Suburban Museum and member of the board of HOKA

Lene Skodborg, MA, East Zealand Museum

Mikkel Thelle, PhD, Danish Center for Urban History

Henning Bro, Ph.D, Frederiksberg City Archives.

Following are four articles based on presentations presented at the 2019-conference 